\title{
Phosphoproteomes of Strongylocentrotus purpuratus shell and tooth matrix: identification of a major acidic sea urchin tooth phosphoprotein, phosphodontin
}

\author{
Karlheinz Mann ${ }^{1 *}$, Albert J Poustka², Matthias Mann ${ }^{1}$
}

\begin{abstract}
Background: Sea urchin is a major model organism for developmental biology and biomineralization research. However, identification of proteins involved in larval skeleton formation and mineralization processes in the embryo and adult, and the molecular characterization of such proteins, has just gained momentum with the sequencing of the Strongylocentrotus purpuratus genome and the introduction of high-throughput proteomics into the field.

Results: The present report contains the determination of test (shell) and tooth organic matrix phosphoproteomes. Altogether 34 phosphoproteins were identified in the biomineral organic matrices. Most phosphoproteins were specific for one compartment, only two were identified in both matrices. The sea urchin phosphoproteomes contained several obvious orthologs of mammalian proteins, such as a Src family tyrosine kinase, protein kinase Cdelta 1, Dickkopf-1 and other signal transduction components, or nucleobindin. In most cases phosphorylation sites were conserved between sea urchin and mammalian proteins. However, the majority of phosphoproteins had no mammalian counterpart. The most interesting of the sea urchin-specific phosphoproteins, from the perspective of biomineralization research, was an abundant highly phosphorylated and very acidic tooth matrix protein composed of 35 very similar short sequence repeats, a predicted N-terminal secretion signal sequence, and an Asp-rich Cterminal motif, contained in [Glean3:18919].

Conclusions: The 64 phosphorylation sites determined represent the most comprehensive list of experimentally identified sea urchin protein phosphorylation sites at present and are an important addition to the recently analyzed Strongylocentrotus purpuratus shell and tooth proteomes. The identified phosphoproteins included a major, highly phosphorylated protein, [Glean3:18919], for which we suggest the name phosphodontin. Although not sequence-related to such highly phosphorylated acidic mammalian dental phosphoproteins as phosphoryn or dentin matrix protein-1, phosphodontin may perform similar functions in the sea urchin tooth. More than half of the detected proteins were not previously identified at the protein level, thus confirming the existence of proteins only known as genomic sequences previously.
\end{abstract}

\section{Background}

Sea urchin is an important model organism for developmental biology and in particular skeletogenesis, providing insight into common principles of biomineralization [1-3]. Like other biominerals, sea urchin skeleton elements are composite materials containing, in addition to

\footnotetext{
* Correspondence: mann@biochem.mpg.de

${ }^{1}$ Max-Planck-Institut für Biochemie, Abteilung Proteomics und Signaltransduktion, D-82152 Martinsried, Am Klopferspitz 18, Germany
}

the mineral component, a small percentage of biopolymers, the organic matrix. This network of organic molecules, pervading the mineral, controls the formation of biominerals and contributes to their final properties [4-6]. Research on the sea urchin model was boosted by the recent publication of the complete Strongylocentrotus purpuratus genome $[7,8]$. The genome sequence enabled the search for potential novel biomineralizationrelated proteins and their transcriptional regulation [9]. It also made possible the direct identification of matrix 
proteins by mass spectrometry-based proteomics, revealing an unexpected complexity of test (shell), spine and tooth proteomes $[10,11]$. However, proteomes cannot be considered complete without determination of posttranslational modifications. One of the most widespread post-translational modifications occurring in proteins of biominerals is phosphorylation [12]. Organic matrices of biominerals as diverse as mammalian tooth and bone [13], chicken eggshell [14] or mollusk shell [15] contain phosphoproteins. In a few cases, such as crustacean orchestin [16], mammalian phosphoryn [17] or osteopontin $[18,19]$, phosphorylation was shown to be crucial for proper folding, calcium binding, and other functionrelated properties of these proteins. Phosphorylation of mammalian extracellular proteins involves casein kinaselike enzymes of the endoplasmic reticulum and Golgi apparatus [12,20,21] and membrane-bound ectokinases $[22,23]$. Although sea urchin is a major model organism for biomineralization studies, data about phosphoproteins in sea urchin skeletal elements are scarce.

At least 353 putative protein kinases were predicted to be encoded in the $S$. purpuratus genome [24]. Some of these kinases apparently play a role in skeleton formation, as shown by kinase inhibition studies in embryos and cultured spicule-producing mesenchymal cells [25-28], where specific kinase inhibitors prevented formation of skeletal elements. However, only one study reported the presence of phosphorylated proteins in a sea urchin mineralized structure, the tooth of Lytechinus variegatus [29]. However, no phosphorylation sites were identified. In test (the commonly used name for the sea urchin shell), phosphate groups were reported to be attached to unidentified matrix molecules [30].

Mass spectrometry has become the method of choice for detection of protein phosphorylation during the last decade because the method is highly sensitive, does not need radioactive labeling, enables determination of the modified amino acids, and does not require purification of the proteins [31]. MS-based phosphoproteomics involves the enzymatic cleavage of mixtures of proteins, fractionation of the peptides by nanoscale liquid chromatography, and analysis by mass spectrometry. However, because phosphopeptides usually constitute only a minor fraction of the peptide mixture used in automated high-throughput analysis of complex mixtures, phosphopeptides are usually enriched and specialized mass spectrometric methods, such as neutral loss-dependent $\mathrm{MS}^{\mathrm{n}}$, have to be used for their detection [32]. The phosphoproteomes of sea urchin test (shell) and tooth organic matrix were analyzed using enrichment of phosphopeptides by reversible adsorption to $\mathrm{TiO}_{2}$ and neutral losstriggered multistage activation [33] in LTQ-Orbitrap and LTQ FT Ultra mass spectrometers. Data were analyzed using MaxQuant [34], a novel integrated suite of algorithms developed for the analysis of high-resolution mass spectrometry data. Using this toolkit, 21 phosphoproteins were identified in test matrix and 15 in tooth matrix.

\section{Materials and methods \\ Preparation of organic matrix}

Sea urchins were killed by freezing. The shells (also called tests) were cut into two halves and emptied. The skeleton elements were soaked in sodium hypochlorite solution (6-14\% active chlorine; Merck, Darmstadt, Germany) for $1 \mathrm{~h}$ with four changes of solution and ultrasonic treatment (Branson Sonifier model 1200) for $5 \mathrm{~min}$ after every change. The cleaned, disconnected calcified elements were washed with water, air dried, and collected separately. Teeth were powdered with mortar and pestle and the powder was washed with sodium hypochlorite again [11]. The water-washed, air-dried test plates and tooth powder were separately demineralized in $50 \%$ acetic acid $(20 \mathrm{ml} / \mathrm{g}$ of dry biomineral) for 14-16 $\mathrm{h}$ at $4-6^{\circ} \mathrm{C}$. The turbid suspension was dialyzed successively against $2 \times 10$ vol. $10 \%$ and $2 \times 10$ vol. $5 \%$ acetic acid at $4-6^{\circ} \mathrm{C}$ (Spectra/Por 6 dialysis membrane, molecular weight cut-off 1000; Spectrum Europe, Breda, The Netherlands). The precipitate, which formed during dialysis, and the clear supernatant were lyophilized together.

\section{Preparation of peptides and enrichment of phosphopeptides}

Test and tooth matrix proteins were carbamidomethylated as before [35] using iodoacetamide instead of iodoacetic acid. Reagents were removed by dialysis against 5\% acetic acid. The protein concentration in carbamidomethylated organic matrix was determined by amino acid analysis in a Biotronik LC3000 analyzer after hydrolysis of the sample in $6 \mathrm{M} \mathrm{HCl}$ for $24 \mathrm{~h}$ at $110^{\circ} \mathrm{C}$.

Organic matrices extracted from a total of nine tests were pooled. Aliquots of $2 \mathrm{mg}$ of carbamidomethylated test matrix were suspended in $10 \mathrm{mM}$ Tris buffer, $\mathrm{pH} 8$, containing $6 \mathrm{M}$ urea and $2 \mathrm{M}$ thiourea, and cleaved with lysyl endopeptidase (Wako Chemicals, Neuss, Germany). After $8 \mathrm{~h}$ the reaction mixture was diluted with $0.05 \mathrm{M}$ ammonium hydrogen carbonate to $2 \mathrm{M}$ urea/ thiourea and trypsin (sequencing grade modified trypsin, Promega, Mannheim, Germany) was added for $14 \mathrm{~h}$ of incubation. In a second approach lysyl endoprotease cleavage products of $2 \mathrm{mg}$ test matrix were further cleaved with endoproteinase Asp-N for $14 \mathrm{~h}$ in $2 \mathrm{M}$ urea (sequencing grade; Roche, Mannheim, Germany). Finally, cleavage products of $2 \mathrm{mg}$ matrix samples were successively cleaved with lysyl endopeptidase $(14 \mathrm{~h})$, trypsin ( $8 \mathrm{~h})$, and endoprotease Asp-N (14 h). The enzyme to matrix ration $(\mathrm{w} / \mathrm{w})$ in proteolytic digests was 
1:50 for lysyl endopeptidase, 1:100 for trypsin and 1:300 for endoproteinase Asp-N. Incubations were performed at room temperature. Reactions were stopped by addition of trifluoroacetic acid to $\mathrm{pH} \sim 2$. Insoluble material was removed by centrifugation and the supernatant was dried by vacuum centrifugation. Each combination of enzymes was applied to three or four $2 \mathrm{mg}$ aliquots.

Tooth matrix extracted from 300 teeth from 60 sea urchins was combined. Aliquots of $1 \mathrm{mg}$ carbamidomethylated matrix were cleaved with combinations of lysyl endopeptidase and trypsin or lysyl endopeptidase $(8 \mathrm{~h}), \operatorname{Asp}-\mathrm{N}(14 \mathrm{~h})$ and trypsin $(8 \mathrm{~h})$, as described for test matrix. Each cleavage method was performed with three aliquots of tooth matrix.

Phosphopeptides were enriched by reversible binding to $\mathrm{TiO}_{2}$ beads (GL Sciences, $10 \mu \mathrm{m}$ beads) in a batch protocol [14,36,37]. Briefly, 2,5-dihydroxybenzoic acid was added to the acidified peptide mixture to a final concentration of $5 \mathrm{mg} / \mathrm{ml}$ and the mixture was incubated with $10 \mathrm{mg}$ of washed beads/sample for $3 \mathrm{~h}$ at room temperature. The mixture was then briefly centrifuged to sediment the beads and the supernatants were incubated for another $3 \mathrm{~h}$ with a fresh batch of beads. The loaded $\mathrm{TiO}_{2}$ beads were washed with $50 \%$ acetonitrile in $0.1 \%$ trifluoroacetic acid, and the bound peptides were eluted with $15 \% \mathrm{NH}_{4} \mathrm{OH}$. The eluted peptide mixtures were acidified to $\mathrm{pH} \sim 2$ with trifluoroacetic acid and cleaned with $\mathrm{C}_{18}$ Stage (stop and go extraction) Tips [37].

\section{LC-MS and data analysis}

$\mathrm{C}_{18}$ reversed phase $\mathrm{LC}$ and mass spectrometric analysis was performed using a Proxeon Easy-nLC (Proxeon Biosystems, Odense, Denmark; software version 2.0) coupled to a LTQ-Orbitrap or LTQ-FT Ultra mass spectrometer (Thermo Fisher Scientific) via a nanoelectrospray ion source (Proxeon Biosystems). Full scans were recorded in the Orbitrap analyzer at a resolution of 60,000 or in the FT-ICR with a resolution of 100,000 (at $m / z=400$ ) followed by MS/MS of the ten most intense peptide ions in the LTQ analyzer. Neutral losstriggered multistage activation (Pseudo $\mathrm{MS}^{\mathrm{n}}$ [33]) for simultaneous fragmentation of neutral loss product and precursor was enabled at $-97.97,-48.99$ and $-32.66 \mathrm{Th}$ relative to the precursor ion, corresponding to a neutral loss of phosphoric acid from singly, doubly and triply charged ions.

Data analysis was performed using MaxQuant v1.0.12.33 [34] http://www.maxquant.org/, a software package making use of the Mascot search engine (Matrix Science, London, UK; version 2.2.04) for database searches. The database used consisted of the Strongylocentrotus purpuratus annotated gene models (Glean3) protein sequence database (ftp://ftp.hgsc.bcm.
tmc.edu/pub/data/Spurpuratus/fasta/Annotation ([7]; see also http://goblet.molgen.mpg.de/cgi-bin/seaurchin-genombase.cgi for further information about Glean [38]), the corresponding reversed database, and the sequences of common contaminants including human keratins from IPIhuman (a total of 58052 sequences). Carbamidomethylation was set as fixed modification. Variable modifications were oxidation (M), N-acetyl (protein), pyro-Glu/Gln (N-term) and phospho (STY). The initial peptide mass tolerance was set to $7 \mathrm{ppm}$ and the MS/ MS tolerance was set to $0.5 \mathrm{Da}$. Two missed cleavages were allowed. The minimal length required for a peptide was seven amino acids. The peptide and protein false discovery rates (FDR) were set to 0.01 . The maximal posterior error probability (PEP), which is the probability of each peptide to be a false hit considering identification score and peptide length [34], was set to 0.01. At least one $\mathrm{MS}^{2}$ spectrum of each identified peptide was manually validated considering the assignment of major peaks, occurrence of uninterrupted y- or b-ion series of at least 3 consecutive amino acids, preferred cleavages $\mathrm{N}$-terminal to proline bonds and C-terminal to Asp or Glu bonds, the possible presence of $\mathrm{a} 2 / \mathrm{b} 2$ ion pairs, the presence of neutral losses from fragments, and mass accuracy. The ProteinProspector MS-Product program http://prospector.ucsf.edu/ was used to calculate the theoretical masses of fragments of identified peptides for manual validation. Localization probability values for phosphorylation sites were derived as described [39]. In addition to kinase motif prediction comprised in MaxQuant, we used NetPhos http://www.cbs.dtu.dk/services/ NetPhos/[40], NetPhosK http://www.cbs.dtu.dk/services/ NetPhosK/[41], and Phosida http://www.phosida.com [42] for phosphorylation site and kinase motif identification and prediction.

BLAST analysis was performed with the program provided by NCBI http://www.ncbi.nlm.nih.gov/blast and by searching against the non-redundant database for all organisms. FASTA and MPsrch search programs were used as provided by the European Bioinformatics Institute (EBI, http://www.ebi.ac.uk) searching against UniProt Knowledgebase and UniProtKB/Swiss-Prot protein sequence databases. Domains were predicted with NCBI Conserved Domain Search [43] and the MotifScan program of http://www.expasy.org/tools.

\section{Results and Discussion \\ Test (shell) matrix phosphoproteins}

The carbamidomethylated matrix of hypochloritewashed test plates contained $15-20 \%$ protein as determined by amino acid analysis (w/w). Not all of the material was soluble in $8 \mathrm{M}$ urea/thiourea, which was used to suspend the matrix before proteolytic degradation. Residual insoluble material was sedimented after 
proteolysis and contained $10-15 \%$ of the total protein by amino acid analysis. These observations agreed with earlier results indicating that a large part of the sea urchin test matrix is not protein $[30,44]$. The highest number of peptides was obtained by cleavage with lysyl endopeptidase and subsequent treatment with trypsin. The other protease combinations yielded only few new peptides and no typical endoprotease Asp-N-derived peptide (Table 1). Altogether 27 unique phosphopeptides from 21 phosphoproteins were identified. These proteins contained 37 phosphorylation sites, the majority of which was identified with a localization probability $\mathrm{p}>0.75$ [39] (Table 1; Additional file 1: Test matrix protein phosphorylation sites; Additional file 2: Selected spectra of test matrix phosphopeptides).

Only two of the test matrix phosphoproteins (P19, SM30-E; Table 1) were identified in recent proteomic studies of spine and test matrix [10] or tooth matrix [11]. This indicates that most of the newly identified proteins were minor components in the matrix of hypochlorite-washed test plates and were detected in the present analysis due to the enrichment for phosphopeptides. The low abundance of phosphoproteins may explain the results of a previous study, which failed to identify any phosphorylated protein in test matrix [30]. Only two of the test matrix phosphoproteins were also identified in tooth matrix (Table 1 , Table 2).

Test matrix phosphoproteins related to biomineralization The only spicule matrix protein found to be phosphorylated was SM30-E (Table 1, Fig. 1), a major component of the test matrix [10]. However, the analyzed peptide mixture contained more non-phosphorylated copies of this peptide than phosphorylated ones, indicating that the protein was only partially modified at this single site. The test (shell) phosphoproteome (Table 1) also included P19, which was previously tentatively associated with mineralization processes because of its specific expression in spicule-forming primary mesenchymal cells of the sea urchin embryo [45]. P19 was recently identified as a phosphoprotein in Lytechinus variegatus teeth, probably as an intracellular component. The phosphorylation sites were, however, not determined [46]. This protein was also detected in the proteome of S. purpuratus tooth tissue previously, but was apparently not an intra-crystalline component because it disappeared from the organic matrix proteome after powdering of the teeth and hypochlorite treatment of the powder to remove residual cellular debris and extracellular matrix [11]. The single phosphorylation site, contained in an acidic peptide, was identified from a complex spectrum of product ions resulting from multiple ion activation events (Fig. 2). The site was not completely occupied since non-phosphorylated versions of this peptide were also identified. The powdered tooth matrix phosphoproteome did not contain this protein (Table 2).

\section{Phosphorylated novel test matrix proteins}

High-quality spectra were obtained for peptides derived from a novel protein (hypothetical protein [Glean3:20139]) [Fig. 3 and Additional File 2: Figs. S1.16, S1.17 and S1.18]. One phosphorylated region, comprising three phosphorylation sites, was sandwiched between an extended proline- and threonine-rich motif and a 70aa-long glutamine-rich motif (Fig. 4). Another phosphopeptide was found in the N-terminal part of the Glu-rich motif (Fig. 4). No known domain signatures or similarities were identified for this sequence in database searches. Another hypothetical protein with multiple phosphorylation was encoded by [Glean3:16285/16293] (Table 1). The 1285 amino acid-long, moderately acidic (calculated pI 5.2) sequence contained a LIM domain (aa50-110), two proline-rich motifs (aa145-186, aa773789) and a bipartite nuclear localization signal (aa773789).

\section{Test matrix phosphoproteins with high similarity to} vertebrate proteins with known function or activities

The test matrix contained several phosphoproteins with known counterparts in vertebrates (Table 1). In many cases the phosphorylation sites of the sea urchin proteins were equivalent to those of mammalian proteins. This is illustrated for a sea urchin protein similar to pleckstrin homology domain-containing F2 [Glean3:18649] in Fig. 5. The human counterpart, PKHF2_HUMAN, has an overall sequence identity of $\sim 63 \%$ to the sea urchin protein and was reported to be phosphorylated at Ser239 [39] and 248 [47]. While Ser239 was conserved and phosphorylated in the sea urchin protein, Ser 248 of the human protein was not present in the sea urchin protein. Another test matrix protein containing a conserved phosphorylation site was the src family kinase SFK3 [Glean3:05419]. The phosphorylated Tyr362 of this kinase is equivalent to phosphorylated Tyr426 of human proto-oncogene tyrosineprotein kinase YES (YES_HUMAN, Uniprot: P07947), which has an overall sequence identity of $\sim 60 \%$ to the sea urchin protein. This tyrosine is a target of autophosphorylation in mammalian c-YES kinase [48]. The members of the $S$. purpuratus Src family have been cloned recently and their recombinantly produced $\mathrm{SH} 2$ domains were shown to be necessary for $\mathrm{Ca}^{2+}$ release at egg fertilization [49]. Also included in this group of proteins with conserved phosphorylation sites were two proteins similar to acidic ribosomal proteins $\mathrm{P} 0 / \mathrm{P} 1 / \mathrm{P} 2$ ([Glean3:15870/27123] and [Glean3:21739]). Both 
Table 1 Test matrix phosphopeptides

\begin{tabular}{|c|c|c|c|c|c|c|}
\hline Glean3_entry & Protein & Peptide & $\begin{array}{l}\text { No. } \\
\text { of } P\end{array}$ & $\begin{array}{c}\text { Best } \\
\text { Motif }\end{array}$ & Cleavage & $\begin{array}{l}\text { Tot. } \\
\text { no. }\end{array}$ \\
\hline $04136^{1 \mathrm{~b}, 2}$ & P19 (Q8MUL3; Sp-P19) & K. ${ }_{33} \mid \mathrm{EEGQASGEGAGEEGK}{ }_{48} . \mathrm{D}$ (Fig. 2) & $1^{3}$ & - & $\begin{array}{l}\mathrm{KR} \\
\mathrm{KD}\end{array}$ & $\begin{array}{l}1 \\
2\end{array}$ \\
\hline $04867^{1 \mathrm{a}, \mathrm{b}}$ & $\begin{array}{l}\text { Similar to SM30 } \\
\text { (Sp-SM30-E) }\end{array}$ & R. ${ }_{76}$ QPGFGNPGTPGGR 88 .Q (Fig. 1) & $1^{3}$ & $\begin{array}{l}\text { ERK } \\
\text { MAPK }\end{array}$ & KR & 2 \\
\hline $05419^{2,4}$ & Src family tyrosine kinase (B6DS93; Sp-SFK3) & R. ${ }_{357}$ IIEDEYIAR $365 . E(S 1.1)$ & 1 & EGFR & KR & 2 \\
\hline $08678^{2}$ & $\begin{array}{l}\text { Similar to protein kinase C-delta } 1 \\
\text { (Sp-Pkcd) }\end{array}$ & K. ${ }_{725}$ VALSPTDTSMLSSINQR ${ }_{741} . \mathrm{Q}(\mathrm{S} 1.2)$ & 2 & CK1 & $K R$ & 1 \\
\hline 11637 & $\begin{array}{l}\text { Hypothetical protein (Leu-rich repeats) } \\
\text { (Sp-Lrr/lgr_14) }\end{array}$ & R. ${ }_{290} \mathrm{LGNLPISR}_{297}$.E (S1.3) & 1 & NEK6 & $\begin{array}{c}\mathrm{KR} \\
\mathrm{KRD}\end{array}$ & $\begin{array}{l}2 \\
3\end{array}$ \\
\hline 13143 & $\begin{array}{l}\text { Hypothetical protein; Glu-rich motif ( aa108-154) } \\
\text { (Sp-Hypp_2072) }\end{array}$ & R. ${ }_{332}$ LITPTNSSDEEEEK $_{345}$.D (S1.4) & 3 & $\begin{array}{l}\text { CAMK2 } \\
\text { CK2 }\end{array}$ & $\begin{array}{c}\mathrm{KR} \\
\mathrm{KRD}\end{array}$ & $\begin{array}{l}3 \\
4\end{array}$ \\
\hline 14937 & $\begin{array}{l}\text { Hypothetical protein; domains: partial Glyco_hydro_30, } \\
\text { lon_trans } \\
\text { (Sp-Trpm3) }\end{array}$ & K. ${ }_{1217}$ NFDDGSLELK 1226 .A (S1.5) & 1 & PLK1 & $\begin{array}{l}\mathrm{KD} \\
\mathrm{KRD}\end{array}$ & $\begin{array}{l}3 \\
1\end{array}$ \\
\hline 15408 & $\begin{array}{l}\text { Hypothetical protein; Glu-rich motif ( aa85-339), Ser-rich } \\
\text { motif ( aa1075-1113) (Sp-Hypp_3054) }\end{array}$ & $\begin{array}{l}\text { K. } 984 \text { QAESSGVSPTNSVGDVPDVIMVDG } \\
\mathrm{NK}_{1009} . \mathrm{T}(\mathrm{S} 1.6)\end{array}$ & 2 & CK1 & KR & 1 \\
\hline $\begin{array}{l}15870 \\
27123^{2}\end{array}$ & Similar to ribosomal protein P1/SP-RPLP1 (Sp-Rpip1) & K. ${ }_{94}$ DESEESDDDMGFGLFD ${ }_{109}-(\mathrm{S} 1.7)$ & 2 & CK1 & $\begin{array}{l}K R \\
K D\end{array}$ & $\begin{array}{l}8 \\
1\end{array}$ \\
\hline \multirow[t]{3}{*}{16285} & $\begin{array}{l}\text { Hypothetical protein/similar to FLJ00139 protein, partial; } \\
\text { domain:LIM2 ( (aa50-110); partial overlap with } \\
\text { Glean3:16293 }\end{array}$ & $\begin{array}{l}\text { R. }{ }_{204} \text { FNASGSPVGSPQLER } 218 . H(S 1.8) \\
\text { R. } 204 \text { FNASGSPVGSPQLER } 218 . H(S 1.9)\end{array}$ & $\begin{array}{l}1 \\
2\end{array}$ & $\begin{array}{l}\text { GSK3 } \\
\text { ERK } \\
\text { MAPK }\end{array}$ & $\begin{array}{l}K R \\
K R\end{array}$ & $\begin{array}{l}1 \\
3\end{array}$ \\
\hline & (Sp-Hypp_126/Sp-Hypp_820) & K. ${ }_{1057}$ PLLSDGEEVEK 1069 .E (S1.10) & 1 & CK2 & $\begin{array}{l}\mathrm{KR} \\
\mathrm{KD} \\
\mathrm{KRD}\end{array}$ & $\begin{array}{c}8 \\
11 \\
19\end{array}$ \\
\hline & & $\begin{array}{l}\text { R. }{ }_{1086} \text { SAALSDDDDQSPVPPAPR }_{1102} \cdot \mathrm{K} \\
(\mathrm{S} 1.11)\end{array}$ & 2 & $\begin{array}{l}\text { PKA, } \\
\text { CK1 }\end{array}$ & $\mathrm{KR}$ & 3 \\
\hline 18255 & $\begin{array}{l}\text { Hypothetical protein; domain: } \\
\text { LIM ( aa673-724); Glu-rich motif ( aa358-564), Ser-rich } \\
\text { motif ( aa595-661) (Sp-Hypp_912) }\end{array}$ & K. ${ }_{332}$ DAVPWIIESPSSDDLK ${ }_{348} . S(S 1.12)$ & 1 & CK1 & $\begin{array}{l}K R \\
K D \\
K R D\end{array}$ & $\begin{array}{l}5 \\
5 \\
3\end{array}$ \\
\hline 18389 & $\begin{array}{l}\text { Hypothetical protein; K-rich motif ( aa211-264) (Sp- } \\
\text { Hypp_2383) }\end{array}$ & $\begin{array}{l}\text { R. } 140 V T P L P V I T E E L S D P E E S P R_{157} . N \\
(S 1.13)\end{array}$ & 1 & CK2 & KRD & 2 \\
\hline $18649^{2}$ & $\begin{array}{l}\text { Similar to pleckstrin homology domain containing, family } \\
\text { F (with FYVE domain) } 2 \\
\text { (Sp-Plekhf2) }\end{array}$ & 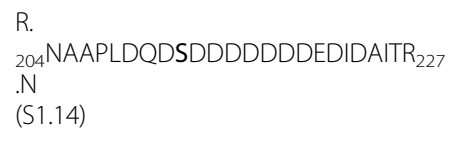 & 1 & - & KR & 6 \\
\hline 18666 & $\begin{array}{l}\text { Hypothetical protein/similar to Arg/Ser-rich splicing factor } \\
4(\text { aa1768-2208) (Sp-Zcchc11) }\end{array}$ & $\begin{array}{l}\text { R. } 1947 \text { DDPDAAEALVPGDDLSEEK }{ }_{1965} \cdot \mathrm{R} \\
(\mathrm{S} 1.15)\end{array}$ & 1 & - & $\begin{array}{l}\mathrm{KR} \\
\mathrm{KD} \\
\mathrm{KRD}\end{array}$ & $\begin{array}{l}7 \\
5 \\
1\end{array}$ \\
\hline \multirow[t]{4}{*}{20139} & $\begin{array}{l}\text { Hypothetical protein } \\
\text { (Sp-Cola2L_2) }\end{array}$ & $\begin{array}{l}\text { R. }{ }_{29} \text { FVQDDSESNEADEDAPR } \\
311 . Y \\
(\mathrm{~S} 1.16)\end{array}$ & 2 & - & $\mathrm{KR}$ & 40 \\
\hline & & $\begin{array}{l}\text { R. } \\
{ }_{295} \text { FVQDDSESNEADEDAPRYPLAPQR } \\
N \\
(S 1.17)\end{array}$ & 2 & - & KR & 3 \\
\hline & & $\begin{array}{l}\text { R. }{ }_{339} \text { NVAEAAGLSSNEVTQVKK } 355 . Q \text { (Fig. } \\
\text { 3) }\end{array}$ & 1 & CK2 & $\begin{array}{l}\mathrm{KR} \\
\mathrm{KRD}\end{array}$ & $\begin{array}{l}22 \\
79\end{array}$ \\
\hline & & R. ${ }_{370} Q Q Q P L P F S E Q Q Q E Y R_{384} . Q(S 1.18)$ & 1 & NEK6 & $\mathrm{KR}$ & 1 \\
\hline 20613 & Hypothetical protein (Sp-Hypp_2525) & K. ${ }_{79} \mathrm{AQDSISSITK}{ }_{88} . \mathrm{E}(\mathrm{S} 1.19)$ & 2 & CK1 & $\mathrm{KD}$ & 2 \\
\hline $21739^{2}$ & $\begin{array}{l}\text { Similar to ribosomal protein P0/P1/P2; also contained in } \\
\text { entry } 11703 \text { (Sp-Arp) }\end{array}$ & $\begin{array}{l}\text { K. } 233 \text { KEESEEESDDDMGFGLFD } 250- \\
\text { (S1.20) }\end{array}$ & 2 & $\begin{array}{l}\text { CK1, } \\
\text { CK2 }\end{array}$ & KR & 3 \\
\hline $24991^{4}$ & Hypothetical protein & R. ${ }_{142} \mathrm{GPSLFGR}_{148} . \mathrm{I}(\mathrm{S} 1.21)$ & 1 & $\begin{array}{l}\text { PKA/ } \\
\text { AKT }\end{array}$ & $\begin{array}{c}\mathrm{KR} \\
\mathrm{KRD}\end{array}$ & $\begin{array}{l}9 \\
3\end{array}$ \\
\hline $25515^{2}$ & Similar to sodium bicarbonate cotransporter (Sp-Slc4a_10) & K. ${ }_{1094} L_{S G S P L P T V R} 1103 . N(S 1.22)$ & 1 & NEK6 & $\begin{array}{l}\mathrm{KD} \\
\mathrm{KRD}\end{array}$ & $\begin{array}{c}6 \\
16\end{array}$ \\
\hline
\end{tabular}


Table 1: Test matrix phosphopeptides (Continued)

\begin{tabular}{|c|c|c|c|c|c|c|}
\hline $26863^{2}$ & $\begin{array}{l}\text { Similar to eukaryotic translation initiation factor } 3 \text {, subunit } \\
8 \\
\text { (Sp-Eif3c) }\end{array}$ & R. ${ }_{35} \mathrm{FFLSDDDEEETK}_{46} \cdot \mathrm{R}(\mathrm{S} 1.23)$ & 1 & CK2 & $\begin{array}{c}\mathrm{KR} \\
\mathrm{KRD}\end{array}$ & $\begin{array}{l}3 \\
8\end{array}$ \\
\hline $\begin{array}{l}27937 \\
11684^{2}\end{array}$ & $\begin{array}{l}\text { Similar to dynein light chain-1 } \\
\text { (Sp-Dynlc2_6a/Sp-Dynlc2_4d) }\end{array}$ & K. ${ }_{47}$ DIASYIKK $_{54}$.E (S1.24) & 1 & EGFR & $K D$ & 1 \\
\hline
\end{tabular}

$1 \mathrm{a,b}$, protein identified previously in test or spine matrix (1a) [10] or tooth matrix (1b) [11]. ${ }^{2}$, known phosphoprotein in sea urchin or other eukaryotic species or similar to a known phosphoprotein. ${ }^{3}$, non-phosphorylated peptide(s) also identified in the present or previous [10,11] studies. ${ }^{4}$, also in tooth matrix phosphoproteome (Table 2). ${ }^{5}$, total number of this phosphopeptide with PEP $<0.01$. KR, cleavage with lysyl endopeptidase and trypsin; KD, cleavage with lysyl endopeptidase and endoproteinase Asp-N; KRD, successive cleavage with lysyl endopeptidase, trypsin and endoprotease Asp-N. Phosphorylation sites with a localization probability $\geq 0.75$ [39] are printed in bold and underlined. Phosphorylation sites with localization probability $0.5-0.75$ are underlined. The entries are ordered according to increasing entry number. For scores and other relevant information see Additional file 1 (Additional file 1: Test matrix protein phosphorylation sites). Annotated best identification spectra are shown in Additional file 2 (Additional file 2: Selected spectra of test matrix phosphopeptides); numbering in brackets is the same as in Additional File 2. SpBase http://sugp.caltech.edu/SpBase/ annotations are given in brackets.

peptides were from the acidic C-terminus of these proteins which contains two phosphoserines as part of casein kinase target sites [50]. Entry [Glean3:08678] encoded a protein with similarity to vertebrate protein kinase C-delta 1 . The identified phosphopeptide derived from the sea urchin protein matches a region of human protein kinase C type delta (KPCD_HUMAN, [Uniprot: Q05655]), which contains several known phosphorylation sites [51]. Thus, phosphorylated Ser736 of the sea urchin protein is equivalent to phosphorylated Ser654 of the human protein. However, we could not unequivocally localize the second phosphorylated residue of this peptide (Table 1). Finally, phosphorylated Ser38 of the sea urchin protein similar to translation initiation factor 3 , subunit 8, [Glean3:26863] was equivalent to phosphorylated Ser39 of the human protein [SwissProt: Q99613] [52].

\section{Tooth matrix phosphoproteins}

Amino acid analysis of carbamidomethylated tooth matrix indicated a protein content of $30-40 \%(\mathrm{w} / \mathrm{w})$. The tooth phosphoproteome isolated from this matrix comprised 15 proteins (Table 2; Additional file 3: Tooth matrix protein phosphorylation sites; Additional file 4: Selected spectra of tooth matrix protein phosphopeptides), eight of which were already identified previously in proteomic analyses of sea urchin skeletal elements $[10,11]$ by means of non-phosphorylated peptides. These included proteins encoded in entries [Glean3:17588] and [Glean3:17590/22278], which belonged to the group of tooth matrix proteins with Ala- and Pro-rich and acidic Gly-rich motifs described previously [11], and [Glean3:13763], which contained a sequence similar to dentin matrix protein-4(DMP-4)/FAM20C, with up to $50 \%$ identity to vertebrate proteins. The acidic C-terminal peptide (Table 2) leading to the identification of this protein was, however, not part of the sequence region of [Glean3:13763] matching to FAM20C/DMP-4 proteins. DMP-4 is a secreted calcium-binding protein abundantly present in dentin and bone [53]. The mouse protein was also reported to be phosphorylated, but at a different site (Phosida database, http://www.phosida. $\mathrm{com} /$ ). The protein was previously tentatively identified in sea urchin tooth matrix with a different, non-phosphorylated, peptide [11] located in the DMP-matching region, but sequence conservation at that particular site was low. The only protein possibly belonging to the SM30 family and found to be phosphorylated was a protein "similar to SM30" [Glean3:00164] (Table 2). This protein was previously tentatively identified in tooth matrix as a minor protein, but was, to the best of our knowledge, not previously mentioned by others as a spicule matrix protein [9]. Only two of the 15 tooth phosphoproteins were also contained in the test phosphoproteome (Tables 1 and 2).

\section{Phosphodontin, the major acidic phosphoprotein of tooth matrix}

The most interesting phosphoprotein, from the point of view of biomineralization, was encoded as a hypothetical protein in entry [Glean3:18919] and yielded 14 unique phosphopeptides. This protein, for which we propose the name phosphodontin, was already previously identified in a proteomic survey of the tooth matrix by means of nonphosphorylated peptides [11], but in that study it appeared as a minor component. In retrospect it is likely that the concentration of this protein was considerably underestimated before, because most of the possible tryptic peptides were phosphorylated. Phosphorylated peptides were, however, not searched for in the previous study and were therefore not included in the calculation of the exponentially modified protein abundance index (emPAI) used as quantification method [11]. The protein sequence of phosphodontin contained a predicted secretion signal sequence (Fig. 6) which was followed by a region composed of thirty-five 11-12 amino acid-long repeats of various modifications of the sequence EISSGEGEQPK. Most repeats coincided with single tryptic peptides, but in two cases the lysine was substituted by Asn, creating tryptic peptides containing two repeats. Another repeat was interrupted by an Arg (aa86-96), and still another one was part of a longer peptide (aa25-51). The 
Table 2 Tooth matrix phosphoproteins

\begin{tabular}{|c|c|c|c|c|c|c|}
\hline Glean3_entry & Protein & Peptide & $\begin{array}{l}\text { No. } \\
\text { of } P\end{array}$ & $\begin{array}{l}\text { Best } \\
\text { Motif }\end{array}$ & Cleavage & $\begin{array}{l}\text { Tot. } \\
\text { no. }\end{array}$ \\
\hline $00164^{1 \mathrm{a}, \mathrm{b}}$ & $\begin{array}{l}\text { Similar to SM-30 } \\
\text { (Sp-Clect) }\end{array}$ & R. ${ }_{204}$ LSEPGFFSFLR $_{215} . \mathrm{E}(\mathrm{S} 2.1)$ & 1 & - & KR & 4 \\
\hline $02353^{2}$ & Similar to nucleobindin $2 \mathrm{a} / \mathrm{b}$ & K. ${ }_{149} \mathrm{DGLSAGLPALK}_{159}$.E (S2.2) & 1 & - & KR & 1 \\
\hline $03345^{2}$ & Dickkopf-1 (aa106-339 of A1XR81_STRPU; Sp-Dkk1)) & K. ${ }_{172} \mathrm{NDGDLLGYLSAESGEK}_{187} \cdot \mathrm{L}(\mathrm{S} 2.3)$ & 2 & CK1 & KR & 8 \\
\hline $05419^{2,4}$ & Src family tyrosine kinase (B6DS93; Sp-SFK3) & R. ${ }_{357}{ }^{\prime I E D E Y I A R}{ }_{365} . E($ Table 1) & 1 & EGFR & KR & 1 \\
\hline 10288 & $\begin{array}{l}\text { Similar to pecanex-like protein 1; domain: partial } \\
\text { Transmembrane protein } 26 \\
\text { (Sp-Tmem26_3) }\end{array}$ & R. VLGTGTLDR .Q (S2.4) & 1 & - & KDR & 4 \\
\hline $10589^{1 a}$ & $\begin{array}{l}\text { Hypothetical protein; pl 4.1, Gly-rich, Asp-rich (Sp- } \\
\text { Hypp_1925) }\end{array}$ & K. ${ }_{245} \mathrm{PIYIPVSVPR}_{254}$.G (S2.5) & $1^{3}$ & - & $\begin{array}{c}\mathrm{KR} \\
\mathrm{KDR}\end{array}$ & $\begin{array}{c}8 \\
11\end{array}$ \\
\hline $13763^{1 a}$ & $\begin{array}{l}\text { Similar to Family with sequence similarity 20, member C/ } \\
\text { Dentin matrix protein 4; domain: DUF1193 } \\
\text { (Sp-Fam20c_1) }\end{array}$ & K. ${ }_{407}$ EAMQPYGSDLDDDDFDF - (S2.6) & 1 & - & KR & 4 \\
\hline 14308 & $\begin{array}{l}\text { Hypothetical protein; domains: EFh; similarity to } \\
\text { reticulocalbin } \\
\text { (Sp-Hypp_112) }\end{array}$ & K. ${ }_{194}{ }^{W}$ ILDSLEDFDTNK $207 . D(S 2.7)$ & 1 & - & $\mathrm{KR}$ & 4 \\
\hline 14805 & $\begin{array}{l}\text { Hypothetical protein; domain: EFh; similarity to multiple } \\
\text { coagulation factor deficiency protein } 2\end{array}$ & K. ${ }_{117} \mathrm{DMSVNQIADAR}_{128} . \mathrm{V}(\mathrm{S} 2.8)$ & 1 & PLK1 & KR & 4 \\
\hline $15125^{1 a}$ & $\begin{array}{l}\text { Hypothetical protein: domain: galactose-3-O- } \\
\text { sulfotransferase (Sp-Gal3st1_6) }\end{array}$ & K. ${ }_{87}$ EDVGGDEESNLASLEGDK $_{104} . \mathrm{D}(\mathrm{S} 2.9)$ & 2 & $\begin{array}{l}\text { GSK3, } \\
\text { CK1 }\end{array}$ & $\begin{array}{c}\mathrm{KR} \\
\mathrm{KDR}\end{array}$ & $\begin{array}{l}2 \\
1\end{array}$ \\
\hline $15906^{1 a}$ & Hypothetical protein (Sp-Hypp_120) & K. ${ }_{1237}$ LSVPQGSPLLSR $_{1248} . C(\mathrm{~S} 2.10)$ & 1 & GSK3 & KR & 1 \\
\hline $17588^{1 a}$ & $\begin{array}{l}\text { Hypothetical protein; Val-, Gly-, Pro-, and Ala-rich regions; } \\
\text { domains: } 2 \text { KAZAL } \\
\text { (Sp-Hypp_136) }\end{array}$ & K. ${ }_{316}$ GVAGGSEDVGK $327 . G($ S2.11) & 1 & - & KR & 4 \\
\hline $\begin{array}{l}17590^{1 a} \\
22278^{1 a}\end{array}$ & $\begin{array}{l}\text { Hypothetical protein/Similar to serotonin receptor 2B; } \\
\text { Val-, Gly-, Pro-, and Ala-rich regions; domains: } 1 \text { KAZAL } \\
\text { (Sp-Hypp_2346) }\end{array}$ & $\begin{array}{l}\text { R. }{ }_{492} \text { APSPAAPSAPR }_{502} \cdot A(S 2.12) \\
\text { R. } \\
{ }_{392} \text { APSAPVRPYAPAPAPQAPSGPSDSSEK }{ }_{418} \\
. Q \\
(\mathrm{~S} 2.13)\end{array}$ & $\begin{array}{l}1^{3} \\
1\end{array}$ & $\begin{array}{l}- \\
\text { CK1 } \\
\text { (SS) }\end{array}$ & $\begin{array}{l}\text { KR } \\
\text { KDR } \\
\text { KR } \\
\text { KDR }\end{array}$ & $\begin{array}{l}3 \\
4 \\
19 \\
13\end{array}$ \\
\hline \multirow[t]{11}{*}{$18919^{1 a}$} & $\begin{array}{l}\text { Hypothetical protein/similar to RPGR/ } \\
\text { phosphodontin; } \\
\text { pl } 3.9\end{array}$ & K. ${ }_{52(63)}$ EMSSGQVEEPK $_{62(73) . E}$ (S2.14) & $1^{3}$ & - & $\begin{array}{l}\text { KR } \\
\text { KDR }\end{array}$ & $\begin{array}{l}3 \\
3\end{array}$ \\
\hline & (Sp-Hypp_2410) & K. ${ }_{74}$ EMSSGEGEEQPK $_{85} . E(S 2.15)$ & 1 & $\begin{array}{l}\text { CK2 } \\
\text { (SS) }\end{array}$ & KR & 3 \\
\hline & & $\begin{array}{l}\text { K. } 97(108,119,130,141,152,163,174) \\
\text { EISSGEGEQPK }_{107(118,129,140,151,162,173,184) \text {. E }} \\
(\text { S2.16) }\end{array}$ & $1^{3}$ & $\begin{array}{l}\mathrm{CK} 2 \\
(\mathrm{SS})\end{array}$ & KDR & 2 \\
\hline & & $\begin{array}{l}\text { K. }{ }_{185(229)} \text { EISSGEEEQPNEISSGEGEEPK }_{206} \\
(250) . \mathrm{E} \\
(\mathrm{S} 2.17)\end{array}$ & 2 & $\begin{array}{l}\text { CK2 } \\
(\mathrm{SS})\end{array}$ & $\begin{array}{l}\mathrm{KR} \\
\mathrm{KDR}\end{array}$ & $\begin{array}{l}10 \\
13\end{array}$ \\
\hline & & K. $218(285)$ EISSGEEEQPK $228(295)$.E (S2.18) & $1^{3}$ & CK2 & $\begin{array}{c}\mathrm{KR} \\
\mathrm{KDR}\end{array}$ & $\begin{array}{l}6 \\
4\end{array}$ \\
\hline & & $\begin{array}{l}\text { K. } 251(296,307) \text { EISSGEGEEPK } 261(306,317) \cdot E \\
(\mathrm{~S} 2.19)\end{array}$ & $1^{3}$ & $\begin{array}{l}\text { CK2 } \\
(\mathrm{SS})\end{array}$ & $\begin{array}{c}\mathrm{KR} \\
\mathrm{KDR}\end{array}$ & $\begin{array}{l}4 \\
4\end{array}$ \\
\hline & & 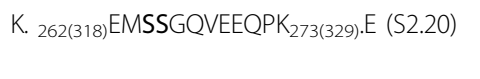 & 1 & - & $\begin{array}{c}\mathrm{KR} \\
\mathrm{KDR}\end{array}$ & $\begin{array}{l}8 \\
2\end{array}$ \\
\hline & & $\begin{array}{l}\text { K. } 274(331,341) \text { EMSSGEGYQPK } 284(340,351) \cdot E \\
(S 2.21)\end{array}$ & 1 & $\begin{array}{l}\text { CK2 } \\
\text { (SS) }\end{array}$ & $\mathrm{KR}$ & 3 \\
\hline & & $\begin{array}{l}\text { K. }{ }_{296} \text { EISSGEGEEPKEISSGEGEEPK } 317 . \mathrm{E} \\
\text { (S2.22) }\end{array}$ & 2 & $\begin{array}{l}\text { CK2 } \\
\text { (SS) }\end{array}$ & $\begin{array}{c}\mathrm{KR} \\
\mathrm{KDR}\end{array}$ & $\begin{array}{l}6 \\
1\end{array}$ \\
\hline & & K. ${ }_{363}$ EVSSGEGEQPK $_{373} . \mathrm{E}(\mathrm{S} 2.23)$ & 1 & $\begin{array}{l}\text { CK2 } \\
\text { (SS) }\end{array}$ & $\mathrm{KR}$ & 4 \\
\hline & & K. ${ }_{374}$EVVSSGQVEELK $_{384}$.G (S2.24) & $1^{3}$ & $\begin{array}{l}\text { CK2 } \\
(\mathrm{SS})\end{array}$ & $\begin{array}{c}\mathrm{KR} \\
\mathrm{KDR}\end{array}$ & $\begin{array}{c}42 \\
8\end{array}$ \\
\hline
\end{tabular}


Table 2: Tooth matrix phosphoproteins (Continued)

\begin{tabular}{|c|c|c|c|c|c|c|}
\hline & & K. ${ }_{385}$ GMSSGEQEEPK $_{395}$.E (S2.25) & 1 & $\begin{array}{l}\text { CK2 } \\
(\mathrm{SS})\end{array}$ & $\begin{array}{l}\mathrm{KR} \\
\mathrm{KDR}\end{array}$ & $\begin{array}{l}3 \\
1\end{array}$ \\
\hline & & K. ${ }_{396} \mathrm{EMSSGEEEQPK}_{406}$.E (S2.26) & 1 & CK2 & KR & 4 \\
\hline & & K. ${ }_{407}$ EMSSGEEEEPK $_{417} . \mathrm{E}(\mathrm{S} 2.27)$ & 1 & CK2 & $\mathrm{KR}$ & 5 \\
\hline $24991^{4}$ & Hypothetical protein & $\begin{array}{l}\text { R. }{ }_{142} \text { GPSLFGR }_{148} \text {.I (see Table } 1 \text { and } \\
\text { Additional File 1) }\end{array}$ & 1 & $\begin{array}{l}\text { PKA } \\
\text { AKT }\end{array}$ & $\begin{array}{c}\mathrm{KR} \\
\mathrm{KDR}\end{array}$ & $\begin{array}{l}13 \\
19\end{array}$ \\
\hline
\end{tabular}

$1 \mathrm{a}, \mathrm{b}$, protein identified previously in test or spine matrix (1a) [10] or tooth matrix (1b) [11]. ${ }^{2}$, known phosphoprotein in sea urchin or other eukaryotic species or similar to a known phosphoprotein. ${ }^{3}$, non-phosphorylated peptide(s) also identified in the present or previous [10,11] studies. ${ }^{4}$, also in tooth matrix phosphoproteome (Table 2). ${ }^{5}$, total number of this phosphopeptide with PEP $<0.01$. KR, cleavage with lysyl endopeptidase and trypsin; KD, cleavage with lysyl endopeptidase and endoproteinase Asp-N; KRD, successive cleavage with lysyl endopeptidase, trypsin and endoprotease Asp-N. Phosphorylation sites with a localization probability $\geq 0.75$ [39] are printed in bold and underlined. Phosphorylation sites with localization probability $0.5-0.75$ are underlined. The entries are ordered according to increasing entry number. For scores and other relevant information see Additional file 1 (Additional file 1: Test matrix protein phosphorylation sites). Annotated best identification spectra are shown in Additional file 2 (Additional file 2: Selected spectra of test matrix phosphopeptides); numbering in brackets is the same as in Additional File 2. SpBase http://sugp.caltech.edu/SpBase/ annotations are given in brackets.

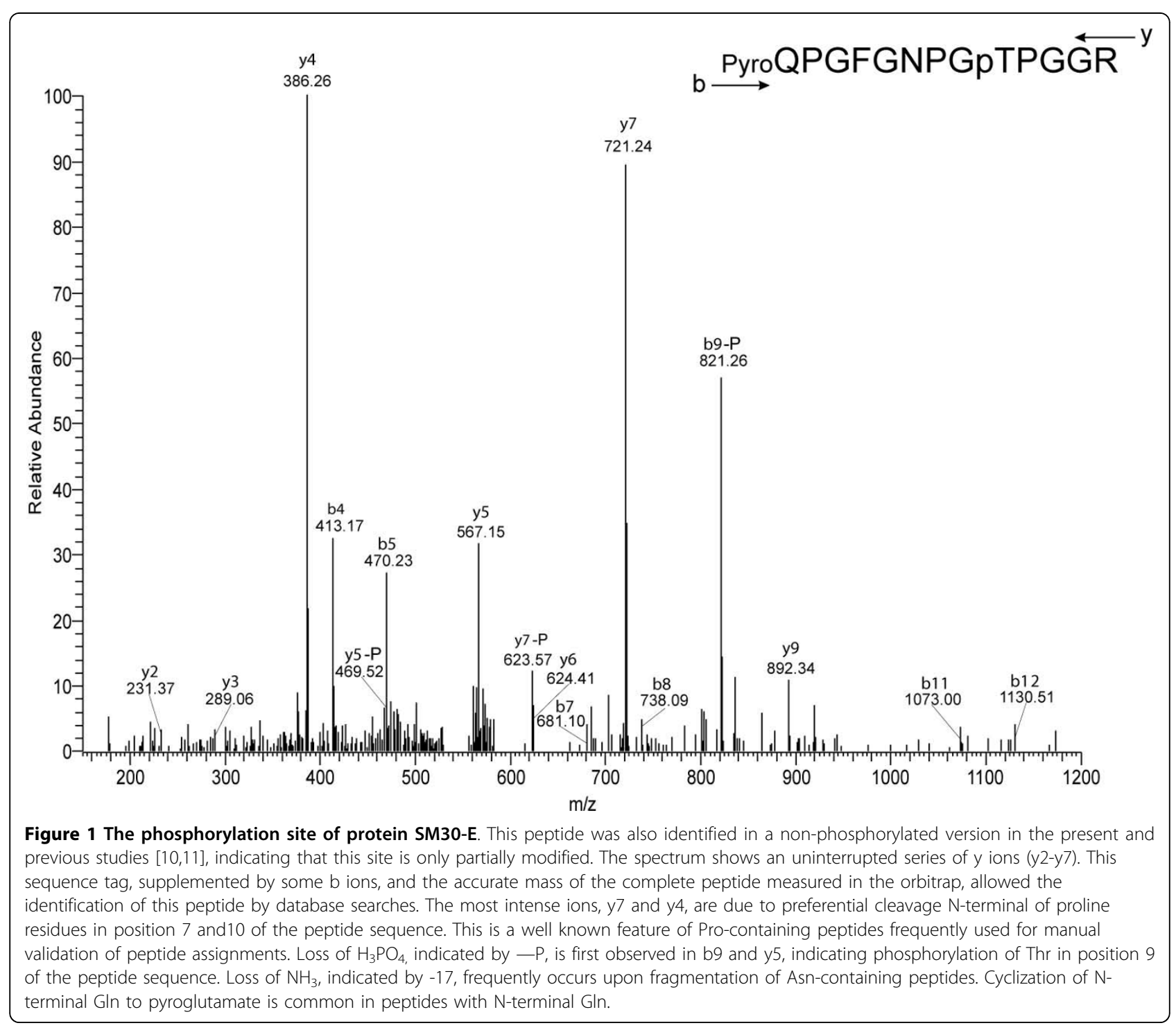




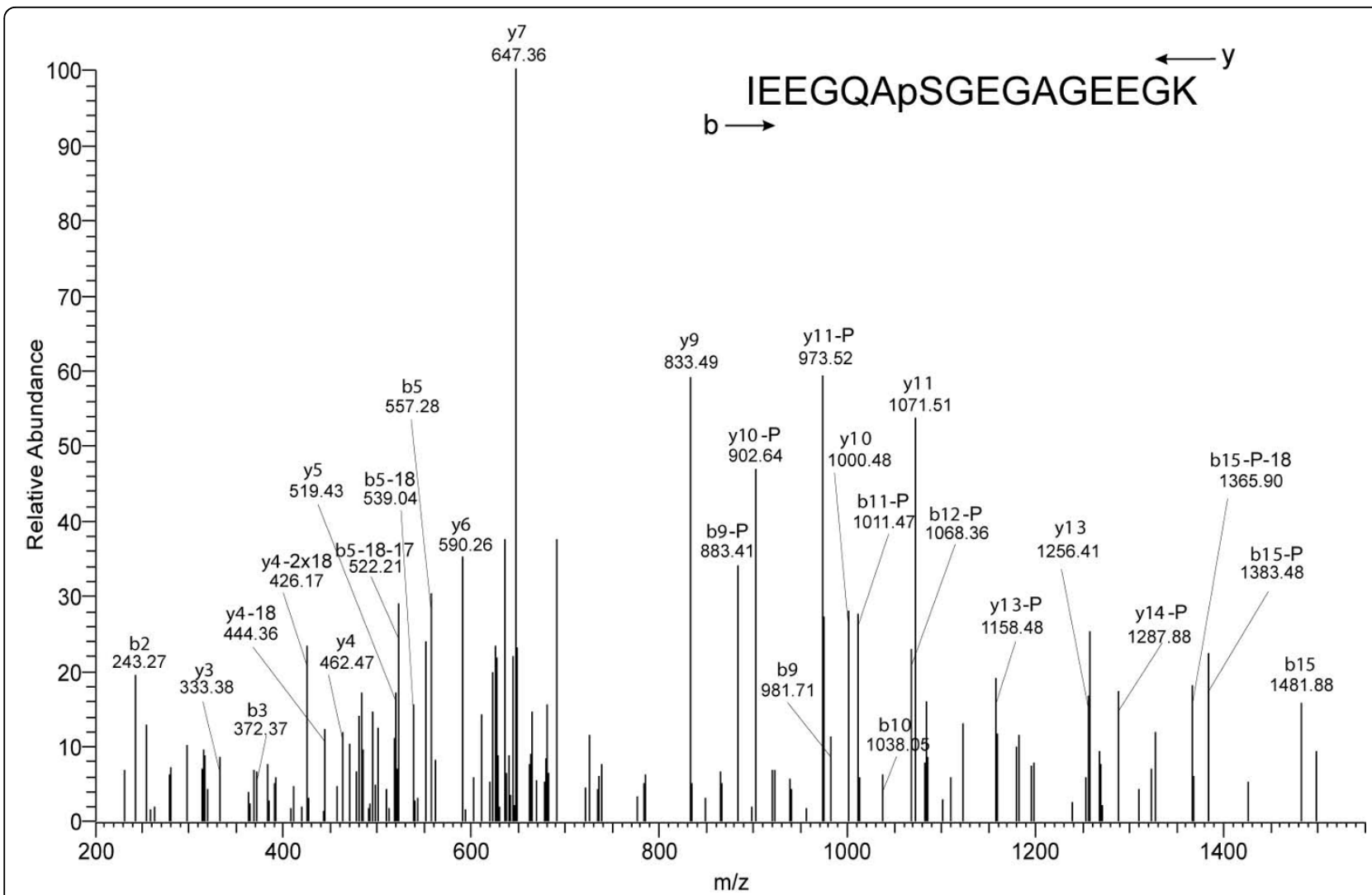

Figure 2 The phosphorylation site of protein P19. This peptide was also identified in a non-phosphorylated version in the present and a previous study [11] indicating that the site is only partially modified. P19 was implicated in biomineralization events previously [45] and was identified as a phosphoprotein in L. variegatus tooth tissue by phosphor-specific staining [46]. However, previous results also indicated that this protein was at best a very minor component of the intracrystalline matrix [11]. A high match of observed to theoretically expected fragments, including a sequence tag of $y 3-y 7$, together with the accurate measurement of the peptide mass, allowed the identification of this peptide. Loss of $\mathrm{H}_{3} \mathrm{PO}_{4}$, indicated by $-\mathrm{P}$, and first observed with y10 indicated the presence of a phospho group at the only serine in the peptide sequence. Loss of $\mathrm{NH}_{3}$ and water is indicated by -17 and -18 , respectively. These neutral losses are frequently observed in peptides containing Glu and Gln.

most C-terminal repeat was truncated. These three latter peptides were not identified by MS/MS. The high percentage of Glu (25\%) in the sequence and a C-terminal domain consisting almost entirely of aspartic acid conferred to this protein a theoretical pI of 3.9, which would be further lowered by phosphorylation. The modified site in each phosphorylated repeat was one of the two serines in position 3 and 4. In general, the evidence (Additional File 3: Tooth matrix protein phosphorylation sites; Additional File 4: Selected spectra of tooth matrix phosphopeptides) favored the second Ser in each repeat as phosphorylation site. However, we cannot exclude that the first Ser was phosphorylated in peptide variants of the same sequence and composition. While the first serine of most repeats would be classified as part of a CK2 target site, the second serine is in most cases not predicted to be part of any kinase target site by MaxQuant (Table 2). The determination of phosphorylation sites was complicated by the frequent presence of Glu as Nterminal amino acid and Met adjacent to the phosphorylation site in many peptides. Glu frequently occurred either in linear form or as pyroGlu, while Met was present unmodified or oxidized. A few peptides were also identified in non-phosphorylated versions in this (Table 2) or a previous study [11]. With the present set of data we cannot determine the total number of phosphates per protein molecule. This is because several repeats occur more than once in the sequence, giving rise to identical peptides. Thus, for instance, repeat EISSGEGGEQPK was contained eight times in the sequence of [Glean3:18919]. However, the number of identified peptides did not correlate to this high frequency (Tab. 2). Peptides arising from this repeat were also identified in unmodified form in this and a previous study [11]. Therefore it is not clear at present how many, and which, of these identical repeats contained occupied phosphorylation sites. The acidity and the high degree of phosphorylation of the protein is reminiscent of some mammalian tooth matrix phosphoproteins, such as dentin phosphoryn, dentin sialoprotein, or dentin matrix protein-1 


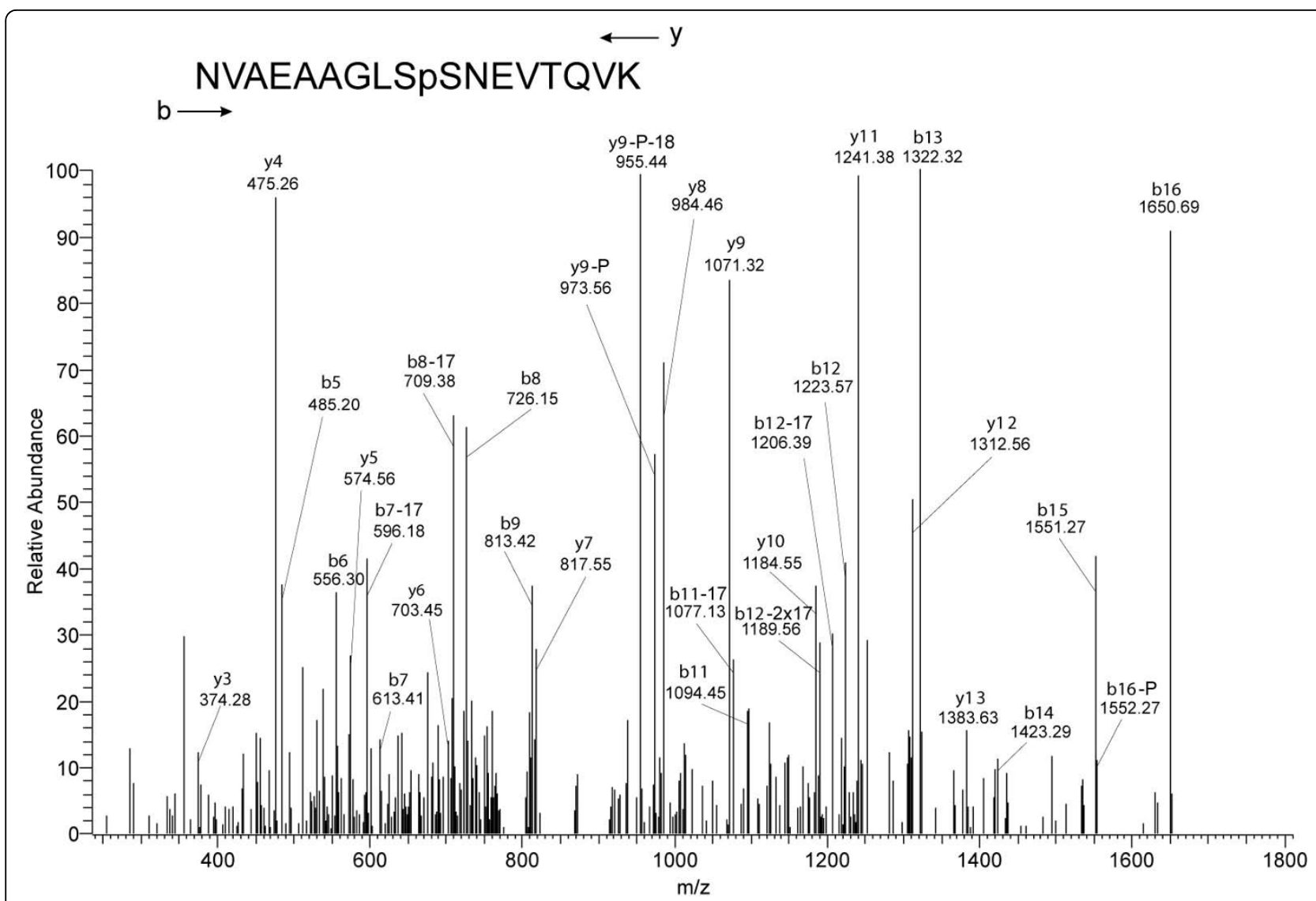

Figure 3 Identification of the phosphorylation site of peptide NVAEAAGLSSNEVTQVK. Similar to the spectrum in Fig. 2, this spectrum shows the complexity to be expected from fragmentation of a relatively long peptide by multistage activation. However, the presence of extended series of $y$ and $b$ ions and the accurate mass of the intact peptide measured in the orbitrap enabled the unequivocal identification of the sequence. The phosphorylation site is identified by the increase of $80 \mathrm{Da}$ in the $y$-ion series starting with $y 8$ and the absence of such an increase in b-ions up to b9. Loss of $\mathrm{H}_{3} \mathrm{PO}_{4}, \mathrm{H}_{2} \mathrm{O}$, and $\mathrm{NH}_{3}$ is indicated by $-\mathrm{P},-18$, and -17, respectively. The neutral loss of water and $\mathrm{NH}_{3}$ is frequently observed upon fragmentation of peptides containing Asn, Gln, Glu, Ser and Thr, also contained in this peptide.

[12], but there is no obvious sequence similarity of phosphodontin to any of these mammalian proteins. The lack of predicted structure indicated that this novel tooth matrix phosphoprotein belongs to the growing group of biomineral matrix proteins without a defined structure in the absence of a ligand [54]. Such intrinsically disordered proteins were shown to be frequent targets of kinases and the phosphorylation sites were less well conserved than phosphorylation sites in well-structured sequence regions of known function [55].

\section{Novel tooth matrix phosphoproteins}

Tooth matrix phosphoproteins not previously detected in sea urchin skeletal elements or the test matrix phosphoproteome included a protein similar to nucleobindin 2a/b (Glean3_02353), dickkopf protein-1 (dkk1; [Glean3:03345], a protein with similarity to pecanex-like protein 1/transmembrane protein 26 [Glean3:10288], a protein similar to reticulocalbin [Glean3:14308] and a protein with similarity to multiple coagulation factor deficiency protein 1 [Glean3:14805]. These proteins were probably minor components of the tooth matrix, which became detectable after depletion of major nonphosphorylated proteins.

Vertebrate nucleobindins are calcium-binding phosphorylated proteins of the nuclear envelope and the endoplasmatic reticulum, but secreted forms were reported to occur in bone matrix and tooth matrix $[56,57]$. The sea urchin protein sequence of [Glean3:02353] was, however, only half the length of vertebrate nucleobindins and contained only one predicted EF hand motif instead of two. Sequence identity to vertebrate proteins was approximately $30 \%$ in an overlapping region, but the phosphorylation site was not part of the overlap.

Entry [Glean3:03345] contained amino acids 106-339 of Uniprot entry [A1XR81:STRPU], likely representing Dickkopf protein (Dkk)-1. Dickkopf proteins are secreted 


\begin{tabular}{|c|c|c|c|}
\hline 1 & MYIVSFVVNV GEVLPVARVT & STPKLMSGKK NRMLLNVTVN & FHETDLTTGV \\
\hline 51 & QGEDLWNMTI WTSRNPNGEG & FAYSVAKNVL TAEQRSQRHR & KGKKFPKLRN \\
\hline 101 & IPYNLDARRM SCNEMREICV & REEQATNPGH SNRAYVPFYF & TGYPDDNVLT \\
\hline 151 & GCTPAPRCKL TKPKPVPTTA & MPTTTRRMTA APTTIQTTWP & PPTQPPTRPP \\
\hline 201 & TRPRTFPPTF PPTLPPRTTR & RPKLKKTKEP IRIPVTLPPT & LAPLTTSMLN \\
\hline 251 & EAFVVGSTRY ATMPPTMPPT & MPPTMRPTMR PTMRPTMRLP & TIQREVQDDS \\
\hline 301 & RYPLAPQRNS & NKRRNRNRRP GWRADRLRNV & AEAAGLS SNE \\
\hline 351 & VTQVKQMKKF RRRQQANQRQ & QQPLPF SEQQ QEYRQQQQRQ & QQQQVYQQQQ \\
\hline 401 & QQQYEQQQQH YRQQQQQQQQ & QYYQQHQQQN RPYAKVQEGQ & MNPLFQREQN \\
\hline 451 & KAIAEGTLLK PHQAWPAAYN & EGYTWQQYMN NQPDSNPAYN & SQGG \\
\hline \multicolumn{4}{|c|}{$\begin{array}{l}\text { Figure } 4 \text { Analysis of the [Glean3:20139] sequence. The Thr- and Pro-rich sequence ( } 25 \% \mathrm{Thr}, 26 \% \text { Pro) is shaded light grey and the Gln-rich } \\
\text { sequence }(63 \% \mathrm{Gln}) \text { is shaded dark grey. Identified phosphopeptides are underlined, phosphorylated Ser are in bold italics. A phosphorylated } \\
\text { region comprising three phospho sites is sandwiched between these two domains, while one phospho site is in the N-terminal region of the } \\
\text { Gln-rich domain. }\end{array}$} \\
\hline
\end{tabular}

inhibitors of the Wnt signaling pathway, which was also implicated in sea urchin development [38]. Human Dkk-1 [39], mouse Dkk-3 [58,59] and chicken eggshell Dkk-3 [14] were reported previously to be phosphorylated at positions found in the same sequence region as the phosphorylation sites of the presumed sea urchin Dkk-1.

Glean3_14308 encoded a sequence with similarity to vertebrate reticulocalbin/calumenin, calcium-binding, EF-hand-containing residents of the ER and Golgi apparatus. The sequence identity of the sea urchin protein to the vertebrate proteins was approximately $30 \%$. However, the sea urchin protein sequence contained a predicted secretory signal sequence and no ER retention signal, such as a C-terminal HDEL, indicating that it was a secreted member of this functionally diverse family of proteins [60].

\section{Concluding remarks}

Using state-of-the-art proteomics instrumentation and software we have detected 21 phosphoproteins in sea urchin test matrix and 15 in tooth matrix. Considering the overlap of two phosphoproteins between these two compartments, we have identified 34 phosphoproteins with 53 unique phosphopeptides containing 64 phosphorylation sites, most of which could be attributed to a single amino acid. Twenty-four phosphorylation sites were not part of a known kinase target site (Tab. 1 and 2). Most of the assigned kinase target sites were casein kinase sites, in agreement with earlier reports indicating that casein kinase-like proteins were largely responsible for the phosphorylation of extracellular proteins. All other assigned sites were part of well-known kinase target sequences, such as EGFR, NEK6 or PKA sites (Tab.

\section{Glean3_18649 203 \\ PKHF2_HUMAN 230

$$
\begin{array}{llll|ll|lll|lllllllll|lllllllll}
\mathrm{R} & \mathrm{N} & \mathrm{A} & \mathrm{A} & \mathrm{P} & \mathrm{L} & \mathrm{D} & \mathrm{Q} & \mathrm{D} & \underline{S} & \mathrm{D} & \mathrm{D} & \mathrm{D} & \mathrm{D} & \mathrm{D} & \mathrm{D} & \mathrm{D} & \mathrm{E} & \mathrm{D} & \mathrm{I} & \mathrm{D} & \mathrm{A} & \mathrm{I} & \mathrm{T} & \mathrm{R} \\
\mathrm{S} & \mathrm{L} & \mathrm{K} & \mathrm{S} & \mathrm{P} & \mathrm{L} & \mathrm{N} & \mathrm{D} & \mathrm{M} & \underline{S} & \mathrm{D} & \mathrm{D} & \mathrm{D} & \mathrm{D} & \mathrm{D} & \mathrm{D} & \mathrm{D} & \mathrm{S} & \underline{S} & \mathrm{D} & - & & & &
\end{array}
$$

Figure 5 Alignment of [Glean3:18649] (Similar to pleckstrin homology domain-containing protein) phosphopeptide to its human counterpart. Phosphoserine 239 [39,47] of the human pleckstrin homology domain-containing family F member 2 protein is also phosphorylated in the homologous sea urchin protein. The phosphorylated serine 248 of human PKHF2 [47] is not conserved in the sea urchin protein. 


\section{MMNRLSNFTF AIMLLVATAT IAMAAPVDQS TNVEAVELPQ EMSSGQVEEP}

\section{KEMSSGQVEE PKEMSSGQVE EPKEMSSGEG EEQPKEISSG EREQPKEISS}

\section{GEGEQPKEI $\underline{S} \underline{S} G E G E Q P K E I$ SSGEGEQPKE I SSGEGEQPK EISSGEGEQP}

\section{KEISSGEGEQ PKEISSGEGE QPKEISSGEG EQPKEISSGE EEQPNEISSG}

201 EGEEPKEISS GEGEQPKEIS S SGEEEQPKEI S SGEEEQPNE I SSGEGEEPK 251 EISSGEGEEP KEMSSGQVEE QPKEMSSGEG YQPKEISSGE EEQPKEISSG 301 EGEEPKEI $\underline{S}$ SEGEEPKEM $\underline{S}$ SGQVEEQPKE MSSGEGYQPK EMSSGEGYQP 351 KEMSSGEGEQ PKEVSSGEGE QPKEV $\underline{S}$ SGQV EELKGMSSGE QEEPKEMSSG

\section{EEEQPKEMSS GEEEEPKEMS SGERNDDTDD DTDDDNDDDD DDDDDDDDDH}

\section{DDNAADGDGD DDY}

Figure 6 The sequence of phosphodontin ([Glean3:18919]), the major phosphoprotein of tooth matrix. The predicted signal sequence and the Asp-rich (72\% Asp) C-terminus are doubly underlined. Alternating sequence repeats are shaded light and dark grey. Possible phosphorylation sites derived from experimental data are printed in bold and underlined. Because several repeats occur in multiple identical copies and also non-phosphorylated copies were detected for several of them, it was not possible to determine the extent of phosphorylation of this protein. Furthermore, obviously only one Ser of each repeat can be phosphorylated at a time. Experimental data favor the second Ser of each repeat as the phosphorylation site, but do not completely exclude modification of the first one. Peptides sequenced by MS/MS are printed in italics.

1 and 2). This was in accordance with a recent report predicting almost the same set of kinases as in humans from in silico analysis of the S. purpuratus genome [24].

Test matrix contained 21 phosphoproteins, only two of which were previously identified as matrix components by means of non-phosphorylated peptides (Table 1). This indicated that all other phosphoproteins were less abundant than the low abundance proteins of the previous proteomic analysis of test matrix [10]. Probably peptides became analyzable only due to the specific enrichment of phosphopeptides. Such minor components likely do not play a role as structural elements but may play a role in signal transduction chains or processing of bulk matrix components. In contrast, eight of the 15 tooth matrix phosphoproteins were previously identified as tooth matrix proteins by means of non-phosphorylated peptides (Table 2). One of them, encoded in entry [Glean3:18919], most probably belongs to the major tooth matrix proteins. In a recent proteomic survey this protein was calculated to be of low abundance only. However, the present study indicated that most of the possible peptides were not taken into account in our previous proteomic survey [11] because the search for phosphorylated peptides was not included. The number of identified and accepted phosphopeptides indicated that this protein, for which we propose the name phosphodontin, would most probably have occupied position two in the abundance ranking [11]. To further characterize phosphodontin it will be necessary to isolate it from tooth matrix in sufficient amounts. Phosphodontin did not show sequence similarity to the better characterized mammalian tooth phosphoproteins. However, properties such as the high degree of phosphorylation and high percentage of acidic amino acids may indicate that this protein has similar functions and importance as the mammalian dental phosphoproteins, and may therefore be an interesting target for future research.

\footnotetext{
Additional file 1: Test matrix protein phosphorylation sites (xls-file). List of scores, phosphorylation site probabilities, possible kinase target motifs, charge, mass, mass errors and intensity of peptides from test matrix proteins as provided by MaxQuant identification and evaluation software. Click here for file

[http://www.biomedcentral.com/content/supplementary/1477-5956-8-6S1.XLS ]
} 
Additional file 2: Selected spectra of test matrix phosphopeptides (docx-file containing embedded eps-files). For each of the unique peptides one spectrum is supplied. Spectra were saved directly from raw-files and annotated manually using and extending annotations provided by MaxQuant.

Click here for file

[ http://www.biomedcentral.com/content/supplementary/1477-5956-8-6S2.DOCX]

Additional file 3: Tooth matrix protein phosphorylation sites (xls-file). List of scores, phosphorylation site probabilities, possible kinase target motifs, charge, mass, mass errors and intensity of peptides from tooth matrix proteins as provided by MaxQuant identification and evaluation software.

Click here for file

[http://www.biomedcentral.com/content/supplementary/1477-5956-8-6S3.XLS ]

Additional file 4: Selected spectra of tooth matrix phosphopeptides (docx-file containing embedded eps-files). For each of the unique peptides one spectrum is supplied. Spectra were saved directly from raw-files and annotated manually using and extending annotations provided by MaxQuant.

Click here for file

[http://www.biomedcentral.com/content/supplementary/1477-5956-8-6S4.DOCX]

\section{Abbreviations}

FDR: false discovery rate; PEP: posterior error probability.

\section{Author details}

${ }^{1}$ Max-Planck-Institut für Biochemie, Abteilung Proteomics und Signaltransduktion, D-82152 Martinsried, Am Klopferspitz 18, Germany. ${ }^{2}$ MaxPlanck-Institut für Molekulare Genetik, Evolution and Development Group, D14195 Berlin, Ihnestrasse 73, Germany.

\section{Authors' contributions}

KM conceived the study, performed organic matrix and peptide isolation and data acquisition. AJP provided the animals. KM and AJP did database searches and annotations. MM supplied methodological expertise. All authors took part in the design of the study and were critically involved in data interpretation and manuscript drafting. All authors read and approved the final manuscript.

\section{Competing interests}

The authors declare that they have no competing interests.

\section{Received: 30 November 2009}

Accepted: 8 February 2010 Published: 8 February 2010

\section{References}

1. Decker GL, Lennarz WJ: Skeletogenesis in the sea urchin embryo. Development 1988, 103:231-247.

2. Wilt FH: The morphogenesis and biomineralization of the sea urchin larval skeleton. Handbook of Biomineralization Weinheim: WileyVCHBäuerlein E 2007, 1:183-210.

3. Ettensohn CA: Lessons from a gene regulatory network: echinoderm skeletogenesis provides insights into evolution, plasticity and morphogenesis. Development 2009, 136:11-21.

4. Cusack M, Freer A: Biomineralization: Elemental and organic influences in carbonate systems. Chem Rev 2008, 108:4433-4454.

5. Wilt FH: Biomineralization of the spicules of sea urchin embryos. Zool Sci 2002, 19:253-261.

6. Killian CE, Wilt FH: Molecular aspects of biomineralization of the echinoderm endoskeleton. Chem Rev 2008, 108:4463-4474.

7. The Sea Urchin Genome Sequencing Consortium: The genome of the sea urchin Strongylocentrotus purpuratus. Science 2006, 314:941-952.

8. Materna SC, Cameron RA: The sea urchin genome as a window on function. Biol Bull 2008, 214:266-273.
9. Livingston $B T$, Killian $C E$, Wilt FH, Cameron A, Landrum MJ, Ermolaeva O, Sapojnikov V, Maglott DR, Buchanan AM, Ettensohn CA: A genome-wide analysis of biomineralization-related proteins in the sea urchin Strongylocentrotus purpuratus. Dev 2006, 300:335-348.

10. Mann K, Poustka AJ, Mann M: The sea urchin (Strongylocentrotus purpuratus) test and spine proteomes. Proteome Sci 2008, 6:22.

11. Mann K, Poustka AJ, Mann M: In-depth, high-accuracy proteomics of sea urchin tooth organic matrix. Proteome Sci 2008, 6:33.

12. George A, Veis A: Phosphorylated proteins and control over apatite nucleation, crystal growth, and inhibition. Chem Rev 2008, 108:4670-4693.

13. Boskey AL: Phosphoproteins and biomineralization. Phosphorus, Sulfur and Silicon 1999, 144(146):189-192.

14. Mann K, Olsen JV, Macek B, Gnad F, Mann M: Phosphoproteins of the chicken eggshell calcified layer. Proteomics 2007, 7:106-115.

15. Borbas JE, Wheeler AP, Sikes CS: Molluscan shell matrix phosphoproteins: Correlation of degree of phosphorylation to shell mineral microstructure and to in vitro regulation of mineralization. J Exp Zoo 1991, 258:1-13.

16. Hecker $\mathrm{A}$, Testenière $\mathrm{O}$, Marin $\mathrm{F}$, Luquet $\mathrm{G}$ : Phosphorylation of serine residues is fundamental for the calcium-binding ability of orchestin, a soluble matrix protein from crustacean calcium storage structures. FEBS Letters 2003, 535:49-54.

17. He G, Ramachandran A, Dahl T, George S, Schultz D, Cookson D, Veis A, George A: Phosphorylation of phosphophosphoryn is crucial for its function as a mediator of biomineralization. J Biol Chem 2005, 280:33109-33114.

18. Hunter GK, Kyle CL, Goldberg HA: Modulation of crystal formation by bone phosphoproteins: structural specificity of the osteopontinmediated inhibition of hydroxyapatite formation. Biochem J 1994, 300:723-728.

19. Gericke A, Qin C, Spevak L, Fujimoto Y, Butler WT, Sorensen ES, Boskey AL: Importance of phosphorylation for osteopontin regulation of biomineralization. Calcif Tissue Int 2005, 77:45-54.

20. Veis A, Sfeir C, Wu CB: Phosphorylation of the proteins of the extracellular matrix of mineralized tissues by casein kinase-like activity. Crit Rev Oral Biol Med 1997, 8:360-379.

21. Lasa M, Chang P-L, Prince CW, Pinna LA: Phosphorylation of osteopontin by Golgi apparatus casein kinase. Biochem Biophys Res Commun 1997, 240:602-605.

22. Zhu X, Luo C, Ferrier JM, Sodek J: Evidence of ectokinase-mediated phosphorylation of osteopontin and bone sialoprotein by osteoblasts during bone formation in vitro. Biochem J 1997, 323:637-643.

23. Suzuki Y, Yamaguchi A, Ikeda T, Kawase T, Saito S, Mikuni-Takagaki Y: In situ phosphorylation of bone and dentin proteins by the casein kinase II-like enzyme. J Dent Res 1998, 77:1799-1806.

24. Bradham CA, Foltz KR, Beane WS, Arnone MI, Rizzo F, Coffman JA, Mushegian A, Goel M, Morales J, Geneviere A-M, Lapraz F, Robertson AJ, Kelkar H, Loza-Coll M, Townley IK, Raisch M, Roux MM, Lepage T, Gache C, McClay DR, Manning G: The sea urchin kinome: A first look. Dev Biol 2006, 300:180-193.

25. Mitsunaga K, Shinohara S, Yasumasu I: Probable contribution of protein phosphorylation by protein kinase $C$ to spicule formation in sea urchin embryos. Dev Growth Differ 1990, 32:335-342.

26. Cervello M, Sanfilippo R, Isola G, Virruso L, Scalia G, Cammerata G, Gambino R: Phosphorylation-dependent regulation of skeletogenesis in sea urchin micromere-derived cells and embryos. Dev Growth Differ 1999, 41:769-775.

27. Kumano M, Foltz K: Inhibition of mitogen-activated protein kinase signaling affects gastrulation and spiculogenesis in the sea urchin embryo. Dev Growth Differ 2003, 45:527-542.

28. Casano C, Savona R, Ragusa MA, Bosco L, Gianguzza F: p38 MAPK activation is required for Paracentrotus lividus skeletogenesis. Caryologia 2008, 61:74-81.

29. Veis DJ, Albinger TM, Clohisy J, Rahima M, Sabsay B, Veis A: Matrix proteins of the teeth of the sea urchin Lytechinus variegatus. J Exp Zool 1986, 240:35-46.

30. Swift DM, Sikes CS, Wheeler AP: Analysis and function of organic matrix from sea urchin tests. J Exp Zool 1986, 240:65-73.

31. Olsen JV, Macek B: High accuracy mass spectrometry in large-scale analysis of protein phosphorylation. Mass Spectrometry of Proteins and Peptides Totowa, New Jersey: Humana PressLipton M, Paša-Tolic L 2009, 131-142. 
32. Macek B, Mann M, Olsen JV: Global and site-specific quantitative phosphoproteomics: principles and applications. Ann Re Pharmacol Toxicol 2009, 49:199-221.

33. Schroeder MJ, Shabanowitz J, Schwartz JC, Hunt DF, Coon JJ: A neutral loss activation method for improved phosphopeptide sequence analysis by quadrupole ion trap mass spectrometry. Anal Chem 2004, 76:3590-3598

34. Cox J, Mann M: MaxQuant enables high peptide identification rates, individualized ppb-range mass accuracies and proteome-wide protein quantification. Nature Biotechnol 2009, 26:1367-1372.

35. Mann K, Siedler F: The amino acid sequence of ovocleidin-17, a major protein of the avian eggshell calcified layer. Biochem Mol Biol Int 1999, 47:997-1007.

36. Larsen MR, Thingholm TE, Jensen ON, Roepstorff $P$, Jorgensen TJ: Highly selective enrichment of phosphorylated peptides from peptide mixtures using titanium dioxide microcolumns. Mol Cell Proteomics 2005, 4:873-886.

37. Rappsilber J, Mann M, Ishihama Y: Protocol for micro-purification, enrichment, pre-fractionation and storage of peptides for proteomics using StageTips. Nature Protocols 2007, 2:1896-1906.

38. Poustka AJ, Kühn A, Groth D, Weise V, Yaguchi S, Burke RD, Herwig R, Lehrach $\mathrm{H}$, Panopoulou $\mathrm{G}$ : A global view of sea urchin expression in lithium and zinc treated sea urchin embryos: new components of gene regulatory networks. Genome Biol 2007, 8:R85.

39. Olsen JV, Blagoev B, Gnad F, Macek B, Kumar C, Mortensen P, Mann M: Global, in vivo, and site-specific phosphorylation dynamics in signaling networks. Cell 2006, 127:635-648.

40. Blom N, Gammeltoft S, Brunak S: Sequence- and structure-based prediction of eukaryotic protein phosphorylation sites. J Mol Biol 1999, 294:1351-1362.

41. Blom N, Sicheritz-Ponten T, Gupta R, Gammeltoft S, Brunak S: Prediction of post-translational glycosylation and phosphorylation of proteins from the amino acid sequence. Proteomics 2004, 4:1633-1649.

42. Gnad F, Ren S, Cox J, Olsen JV, Macek B, Oroshi M, Mann M: PHOSIDA (phosphorylation site database): management, structural and evolutionary investigation, and prediction of phosphor sites. Genome Biol 2007, 8:R250.

43. Marchler-Bauer A, Bryant SH: CD-Search: Protein domain annotations on the fly. Nucl Acids Res 2004, 32:W327-W331.

44. Weiner S: Organic matrix-like macromolecules associated with the mineral phase of sea urchin skeletal plates and teeth. J Exp Zool 1985, 234:7-15.

45. Illies MR, Peeler MT, Dechtiaruk AM, Ettensohn CA: Identification and developmental expression of new biomineralization proteins in the sea urchin Strongylocentrotus purpuratus. Dev Genes Evol 2002, 212:419-431.

46. Alvares K, Dixit SN, Lux E, Veis A: Echinoderm phosphorylated matrix proteins UTMP16 and UTMP 19 have different functions in sea urchin tooth mineralization. J Biol Chem 2009, 284:26149-26160.

47. Dephoure N, Zhou C, Villen J, Beausoleil SA, Bakarlarski CE, Elledge SJ, Gygi SP: A quantitative atlas of mitotic phosphorylation. Proc Natl Acad SC USA 2008, 105:10762-10767.

48. Ariki M, Tanabe $O$, Usui $H$, Hayashi $H$, Inoue $R$, Nishito $Y$, Kagamiyama $H$, Takeda M: Identification of autophosphorylation sites in c-Yes purified from rat liver plasma membranes. J Biochem 1997, 121:104-111.

49. Townley IK, Schuyler E, Parker-Gür M, Foltz KR: Expression of multiple Src family kinases in sea urchin eggs and their function in $\mathrm{Ca}^{2+}$ release at fertilization. Dev Biol 2009, 327:465-477.

50. Hasler P, Brot N, Weissbach H, Parnassa AP, Elkon KB: Ribosomal proteins $\mathrm{P} 0, \mathrm{P} 1$, and $\mathrm{P} 2$ are phosphorylated by casein kinase II at their conserved carboxyl termini. J Biol Chem 1991, 266:13815-13820.

51. Daub H, Olsen JV, Baierlein M, Gnad F, Oppermann FS, Koerner R, Greff Z, Keri G, Stemmann O, Mann M: Kinase-selective enrichment enables quantitative phosphoproteomics of the kinome across the cell cycle. Mol Cell 2008, 31:438-448.

52. Gevaert K, Staes A, Van Damme J, De Groot S, Hugelier K, Demol H, Martens L, Goethals M, Vandekerckhove J: Global phosphoproteome analysis on human HepG2 hepatocytes using reversed-phase diagonal LC. Proteomics 2005, 5:3589-3599.

53. Hao J, Narayanan K, Muni T, Ramachandran A, George A: Dentin matrix protein 4 , a novel secretory calcium-binding protein that modulates odontoblast differentiation. J Biol Chem 2007, 282:15357-15365.
54. Evans JS: Tuning in to mollusk shell nacre- and prismatic-associated protein terminal sequences. Implications for biomineralization and the construction of high performance inorganic-organic composites. Chem Rev 2008, 108:4455-4462.

55. Landry CR, Levy ED, Michnik SW: Weak functional constraints on phosphoproteomes. Trends in Genetics 2009, 25:193-197.

56. Wendel $M$, Sommarin $Y$, Bergman $T$, Heinegard D: Isolation, characterization, and primary structure of a calcium-binding $63-\mathrm{kDa}$ bone protein. J Biol Chem 1995, 270:6125-6133.

57. Somogyi E, Petersson U, Sugars RV, Hultenby K, Wendel M: Nucleobindin a calcium-binding protein present in the cells and mineralized tissues of the tooth. Calcif Tissue Int 2004, 74:366-376.

58. Villen J, Beausoleil SA, Gerber SA, Gygi SP: Large-scale phosphorylation analysis of mouse liver. Proc Natl Acad Sci USA 2007, 104:1488-1493.

59. Zanivan S, Gnad F, Wickstroem SA, Geiger T, Macek B, Cox J, Faessler R, Mann M: Solid tumor proteome and phosphoproteome analysis by high resolution mass spectrometry. J Proteome Res 2008, 7:5314-5326.

60. Honoré B: The rapidly expanding CREC protein family: members, localization, function, and role in disease. Bioessays 2009, 31:262-277.

doi:10.1186/1477-5956-8-6

Cite this article as: Mann et al:: Phosphoproteomes of Strongylocentrotus purpuratus shell and tooth matrix: identification of a major acidic sea urchin tooth phosphoprotein, phosphodontin. Proteome Science 2010 8:6.

\section{Submit your next manuscript to BioMed Central and take full advantage of:}

- Convenient online submission

- Thorough peer review

- No space constraints or color figure charges

- Immediate publication on acceptance

- Inclusion in PubMed, CAS, Scopus and Google Scholar

- Research which is freely available for redistribution

Submit your manuscript at www.biomedcentral.com/submit
C Biomed Central 